\title{
On-line marketing $v$ neziskové organizaci: Analýza webových stránek organizací Královéhradeckého kraje
}

\author{
On-line Marketing in Nonprofit Organization: Website Analysis \\ of Organizations in the Královéhradecký Region
}

Pavel Bachmann

\begin{abstract}
For non-profit organizations, the Internet represents an unprecedented and highly costeffective opportunity to build and enhance relationships with supporters, volunteers, clients and the community they serve (Hart 2006). This study's main goal is to map out the current level of on-line marketing realized by 182 nonprofits in the Královéhradecký Region through their websites. The following five research questions are used to accomplish this goal. RQ1: What is the percentage of nonprofits that have a website available? What is the extent of website accessibility, address intuitiveness and website up-to-datedness? RQ2: How is the organization's mission presented on the website? RQ3: How does the website support online donations to the non-profit? RQ4: How does the website support partnership between the organization and the public (e.g., long-term relationships, nonfinancial assistance, professional consultations, volunteering, and involvement with social sites)? RQ5: What level of quality of online marketing do the organizations offer?
\end{abstract}

KEY WORDS on-line marketing, website, non-profits, Královéhradecký region, Czech Republic

\section{Úvod}

Marketing má dnes mnoho podob a oblastí využití. Tradičně byl spojován s podnikovým sektorem, jeho rozšśření do neziskového sektoru v šedesátých a sedmdesátých letech minulého století dokumentují napríklad publikace Kotlera a Levyho (1968) nebo Shapira (1974). $\mathrm{V}$ devadesátých letech se začal rozvíjet fenomén internetu. Společnost se mění a internet se stává běžným zpo̊sobem života především pro mladší věkové skupiny obyvatel (Veselá a Šmahel 2009). Marketing pak přirozeně tuto skutečnost následuje a vzniká ve své on-line podobě.

Přístup neziskových organizací k marketingu se může, podobně jako samotný charakter organizace, velmi lišit. Závisí jen na organizaci samotné, který z prrístupů učiní součástí

Sociálni studia. Katedra sociologie FSS MU, 3/2011. S. 97-110. ISSN 1214-813X. 
své strategie. Marketing se sám o sobě postupně vyvíjí (Kotler 1994), konzervativní pojetí opřené o tradiční marketingový mix v podobě „4P“ (product, price, place, promotion) je nahrazováno modernější a na zákazníka více orientovanou koncepcí „4C“ (customer value, customer's total costs, convenience a communication) (viz např́klad Blažková 2005). U organizací zaměřených na služby (většina neziskových organizací) se tento zákaznický mix rozšiřuje dále o interaktivní marketing (obsahující internetovou komunikaci), marketing událostí a virální marketing (Kotler a Keller 2007, Vaštíková 2008). Situace typické pro tržní prostředí ale v neziskovém prostředí nemusí plně fungovat. Zatímco tržní organizace se orientují zpravidla pouze na zákazníka, tak u netržní organizace je zaměření bud' dvousložkové, jak zmiňuje Vaštíková (2008), tvořené donátorem (přispívatel, dárce) a zákazníkem (návštěvník, klient, volič, pacient atd.), nebo dokonce vícesložkové.

Složitost aplikace marketingu v neziskovém prostředí vysvětluje Drucker (1994), když říká, že zatímco zisková organizace se zajímá především o to, zda si zákazník zboží nebo službu koupí, produktem neziskové organizace jsou změněné lidské osobnosti. V nonprofitních oblastech, jako jsou sociální práce, výchova a vzdělávání nebo péče o kulturní dědictví, tedy organizace nemůže reagovat přímo na krátkodobé přání svého zákazníka. Krátkodobé cíle neziskové organizace totiž mnohdy směřují proti „přáni““ klienta (musí např́íklad docházet do zaměstnání, opustit blízkou komunitu, vzdělávat se atd.). Právě proto je marketing v neziskovém sektoru specifický. Proměnou takových nesprávných přání klienta na ta správná se zabývá sociální marketing. Sargeant (2005) zmiňuje, že sociální marketing se poprvé objevil, když se v sedmdesátých letech minulého století zjistilo, že marketingové nástroje a techniky, typicky aplikované na výrobky a služby, mohou být stejně dobře využity i pro marketing názorů a myšlenek.

Při pohledu na stav marketingového řízení v českých neziskových organizacích je třeba připomenout Zprávu o stavu neziskového sektoru v České republice (2009), která domácím „neziskovkám“ vytýká řadu nedostatků. Podobnou skutečnost uvádějí i předchozí zprávy o stavu neziskového sektoru. Nedostatky mohou vyplývat z celé řady skutečností. Důvody, proč se organizace zdráhají využívat marketing, formuloval naprríklad Sargeant (2005) takto:

- filantropicky vykonávaná práce si zaslouží podporu sama o sobě (není třeba ji dále propagovat);

- zjištování marketingových potřeb bude př́liš agresivní k respondentům;

- marketing sníží vnímanou kvalitu (pokud začneme propagovat, může to u stávajících klientů vyvolat pocit, že kvalita produktu poklesla);

- marketing je nemorální (námitka vychází z nepochopení konceptu marketingu a často je vznesena proto, že marketing je viděn jako manipulace se zákazníky);

- marketing potlačuje inovativnost (organizace se namísto toho, aby přemýšlela nad obsahem služby, zamýšlí nad tím, jak produkt prodat).

Hart (2006) konstatuje, že právě on-line marketing poskytuje neziskovým subjektům dříve nemožnou a velmi nákladově efektivní př́ležitost vybudovat si a zlepšit vztahy se svými podporovateli, dobrovolníky, klienty a cílovou skupinou, které slouží. Systematická a promyšlená e-mailová komunikace a dobře strukturovaná a informativní webová stránka je klíčem k dosažení úspěchu. Neziskové organizace by ve své komunikaci měly nejdříve vhodně využívat internetové nástroje, a až poté přistupovat $\mathrm{k}$ fundraisingu. Úspěch přijde 
nikoli na základě důrazu na technologii, ale na základě kultivace a zlepšení vztahů (Drucker 1994, Sargeant 2005, Ledvinová 2006). Právě prostřednictvím dobře navržené webové stránky mohou organizace nejen oslovit širokou veřejnost a budovat s ní vztah, ale také šetřit finanční prostředky vynakládané na reklamní a PR iniciativy v tradiční podobě. Navíc webové funkce jako podcasting a blogy umožňují zacílení na mladší cílové skupiny (Ingehoff a Kelling 2009).

\section{Cíle studie}

Klíčovým cílem předložené studie je vymezit současnou situaci v oblasti on-line marketingu českých neziskových organizací, a to na prŕkladu organizací se sídlem v Královéhradeckém kraji. ${ }^{1}$ Problematika on-line marketingu neziskových organizací není v České republice dosud detailněji zmapována, dílčí výsledky nabízí pouze práce Rohrbachera (2007) nebo pravidelné zveřejňování Zprávy o stavu neziskového sektoru České republiky (Zpráva o stavu, 2009). Zmíněná situace byla příčinou volby vlastního přístupu s využitím zahraničních zkušeností (Arnold a Tapp 2003, Hart 2002), respektive výzkumů provedených v sektoru veřejné správy (Gandía a Archidona 2008; Komárková, Máchová a Bednarčíková 2008; Bachmann 2010). Na základě těchto výzkumů byly pro účely naplnění cíle vymezeny jednotlivé výzkumné otázky (u otázek jsou uvažovány vždy webové stránky neziskových organizací zahrnutých do výzkumu).

\section{Mají organizace vlastní webové stránky? Je stránka snadno př́istupná, adresa intui- tivní a stránky aktuálni?? \\ První výzkumná otázka se zaměřuje na zjištění podílu organizací s dostupnou webovou prezentací, na otázku aktuálnosti webových stránek a snadnost př́istupu na webové stránky. Nutnost př́tomnosti organizace na webu zdůrazňují již Smith, Bucklin a kol. (2000: 270): „Webové technologie mohou podpořit řadu neziskových činností, proto by všechny organizace měly být př́tomny na internetu, čehož mohou dosáhnout i při nízkých nákladech." Podobně jiní autoři (Gehrke a Turban 1999, Hart 2006) podtrhují, že webová stránka je v součas- nosti jednou ze základních nutností každé organizace, včetně neziskové. Šedivý a Medlíková (2009) upozorňují, že pokud organizaci někdo nezná a má zájem se o ní něco dozvědět, tak lze předpokládat, že jako jednu z prvních cest zvolí webovou stránku. Rohrbacher (2007) uvádí ve svém výzkumu zaměřeném na česká občanská sdružení čtvrtinový podíl organizací $\mathrm{s}$ dostupnou webovou stránkou. Na požadavky snadného př́stupu $\mathrm{k}$ webové stránce, intui- tivnosti webové adresy a aktuálnosti stránek pak upozorn̆ují Hart a kol. (2010), když mezi základními kritérii správy webu zmiňují např́iklad vyhledatelnost (lidé by měli vaši stránku snadno nalézt, bud's využitím vyhledávače, nebo jiným způsobem; jinak, i když máte výborné stránky, tak toho moc nepřinesou, protože je případní příchozí nemohou najít) nebo přilnavost (většina návštěvníků stráví na vašich stránkách pravděpodobně méně než 30 vteřin; nemají}

Výběr pouze jednoho kraje vyplývá z potřeby zachování konzistence výběrového vzorku. Pro provedení výběru napríčc celou ČR neexistuje celostátní databáze zahrnující všechny druhy NNO, která by umožnila realizovat alespoň částečně reprezentativní výběr. 
tedy čas na to, aby udělali cokoli na vaši podporu; přilnavá stránka udrží návštěvníky na stránkách přinejmenším na dvě až tři minuty, aby mohli provést transakci, a snad ještě mnohem déle). Zatímco vyhledatelnost se týká zejména webové adresy, přilnavost bude dále (z důvodu obtížnosti měření) vztažena pouze k aktuálnosti webové prezentace.

\section{Jak organizace prezentuji své posláni?}

Prezentace poslání je pro každou neziskovou organizaci nezbytná z důvodu ospravedlnění své existence vůči veřejnosti. Vaštíková (2008) uvádí, že „využívá-li nezisková organizace orientaci na donátory, čili tzv. strategie ,po proudu', je nezbytnou potřebou neziskové organizace jasně a veřejně vysvětlit její poslání“. Drucker (1994) a obdobně později Ledvinová (2006) zdůrazňují význam poslání pro dárce. Zmiňují, že dárci jsou nejčastěji přesvědčeni smysluplným vyjádřením poslání organizace.

\section{Jaké možnosti on-line dárcovství jsou na webu nabízeny?}

Na současný stav v oblasti on-line dárcovství upozorňuje Petr Machálek, ředitel Hnutí Duha, když říká, že českým neziskovým organizacím zatím chybí snadný přístup k moderním platebním metodám, jež dárcům usnadní možnost podporovat jimi vybrané dobročinné projekty. Ředitel Nadace Via Jiří Bárta následně dodává, že ze zahraničních zkušeností je zřejmé, že snadná, bezpečná a rychlá možnost, jak dar poskytnout, přivádí k dárcovství nové skupiny dárců (Nadace Via 2010).

4. Umožňují webové stránky navázání partnerství s veřejností (udržení vztahu, materiálni pomoc, konzultace, dobrovolnictvi aj.)?

Kromě poslání je efektivita on-line marketingu ovlivněna dalšími faktory. Prvním z nich je dlouhodobost vztahu. „Déletrvající kontakt dokáže probudit důvěru dárce a jeho ochotu dávat nejen opětovně, ale i vyšší částky“ (Sargeant 2005). Platební metody budou funkční především při oslovení takových dárců, kteří chtějí poskytnout pomoc finančního charakteru. Nezisková organizace však pro svou činnost může využít i podporu materiální, odborné konzultace či zapojení dobrovolníků, proto je otázkou, do jaké míry v této oblasti oslovuje veřejnost. Pro zajištění pravidelného kontaktu s organizací je však v současné době nutné použít i fenoménu sociálních sítí, jako jsou Facebook, Twitter a další. Ukazuje se totiž, že zejména u mladší generace tyto technologie zaujímají stále větší prostor (Hart a kol. 2010, Veselá a Šmahel 2010). Kromě toho, dle Jae a kol. (2008), pro vytvoření hodnoty pro organizaci i zákazníky jsou stále využívány on-line komunity. Přidávají hodnotu budováním povědomí o značce a image organizace, zajištěním př́stupu k organizaci pro loajální zákazníky, zvýšením stability vztahu s dodavatelem a vytvářením př́imů od existujících a nových zákazníků.

\section{Jaká je celková úroveň poskytovaného on-line marketingu?}

Jedná se o prvotní studium v dané oblasti, tudíž výsledky nemohou být komparovány $\mathrm{s}$ jinými výzkumy. $\mathrm{Z}$ toho důvodu bude cílem této otázky poskytnout základní údaje o kvalitě on-line marketingu uskutečňovaného na webových stránkách zkoumaných neziskových organizací. Mimoto bude získána informace o rozdílnostech kvality mezi jednotlivými neziskovými organizacemi podle jejich působnosti, právní formy nebo členství v zastřešující 
organizaci. V předchozích výzkumech Bachmann (2011) poukazuje na významnou odlišnost transparentnosti neziskových organizací dle oblasti, ve které organizace působí. Vyšší úroveň transparentnosti vykazovaly zejména organizace s registrovanými sociálními službami.

\section{Metodika výzkumu}

Studie využívá formu obsahové analýzy webových prezentací neziskových organizací. Odborná veřejnost $\mathrm{v}$ tomto př́ípadě hovoří o internetem zprostř̌edkovaném výzkumu, respektive analýze dokumentů realizované v kontextu internetového výzkumu. Taková analýza dokumentů je obdobná určitým formám pozorování, nicméně záznamy jsou na webovou sít' primárně ukládány s určitým účelem. Internet poskytuje různé druhy on-line dokumentů. Škála začíná u dokumentů s informačním nebo uměleckým obsahem, přes teoretické a vědecké články a končí povídkami, poezií a sdílením osobních zkušeností. Na internetu je tedy možné využít všechny tradiční výzkumné prŕistupy, kvalitativní, kvantitativní i jejich kombinaci (Hewson 2007, Blažková 2005).

Předmětem výzkumu byly neziskové organizace vymezené dle $\mathrm{v}$ českém prostředí obecně užívané definice Salomona a Anheiera (např́klad Benáček, Frič a Potůček 2008). Neziskový subjekt je zde definován na základě naplnění kritérií institucionalizace, soukromého charakteru, nerozdělování zisku pro potřeby zakladatelů, samostatného řízení a dobrovolnosti. Definici v české praxi naplňují především organizace následujících právních forem: 1) občanská sdružení, 2) obecně prospěšné společnosti, 3) nadace a nadační fondy, 4) církve a jejich účelová zařízení a 5) zájmová sdružení právnických osob.

Pro účely studie bylo využito sběru dat ze dvou veřejně dostupných databází neziskových organizací. ${ }^{2}$ Jednalo se o Evidenci nestátních neziskových organizací (dále jen ENNO) a Regionální informační servis (dále jen RIS). ENNO je provozována Ministerstvem vnitra. Správnost informací zveřejněných v evidenci je ověřována při zavedení organizace do registru i při dalších významných změnách jejích údajů. Př́ítomnost v ENNO je jedním z ukazatelů věrohodnosti neziskové organizace, jelikož jsou zadané informace ověřovány a kontrolovány, mohou být přesvědčivé a důvěryhodné pro př́ípadné dárce, partnery, dobrovolníky či zaměstnance. ${ }^{3}$ Databáze RIS byla zřízena Centrem pro regionální rozvoj, státní př́spěvkovou organizací založenou ministerstvem pro místní rozvoj. Cílem databáze je shromáždit a provázat různorodé datové zdroje informující o České republice a jednotlivých regionech a zpř́ístupnit jejich výstupy zejména ústředním orgánům, ale také odborné veřejnosti.

2 V ČR neexistuje celostátní databáze nestátních neziskových organizací zahrnující všechny druhy NNO. K dispozici jsou pouze neúplné evidence obsahující pouze přibližně desetinu všech těchto subjektů (ENNO, RIS, katalog neziskových organizací na serveru www.neziskovky.cz). Z hlediska jednotlivých právních forem je k dispozici např́ílad „Seznam občanských sdruženi““ dostupný na webových stránkách Ministerstva vnitra ČR.

3 V horizontu několika let má vzniknout také povinnost zapsat se do Evidence NNO pro všechny NNO působící v České republice. Evidované NNO budou moci jednodušeji získat dotace z veřejné správy a žádat daňové úlevy pro svou činnost. 
Po selekci dat pouze na subjekty Královéhradeckého kraje byla získaná data obou databází sloučena a získán vzorek 182 organizací. Dalším krokem výzkumu bylo získání adres webových stránek daných organizací. V databázi RIS byly adresy součástí shromažd'ovaných dat, u organizací z databáze ENNO bylo provedeno vyhledání adresy prostřednictvím vyhledávače Google. Získané webové stránky organizací byly následně předmětem analýzy v dřive jmenovaných výzkumných oblastech. Pro hodnocení výsledků analýzy byla využita kritéria a hodnoticí postupy uvedené v tabulce 1.

Tabulka 1: Popis zpưsobu a kritérii hodnocení výsledků zjištěných v rámci výzkumných otázek

\begin{tabular}{|c|c|}
\hline Výzkumná otázka & Způsob a kritéria hodnocení \\
\hline $\begin{array}{l}\text { 1: Vlastní webová stránka, } \\
\text { př́stupnost, intuitivnost adresy a } \\
\text { aktuálnost }\end{array}$ & $\begin{array}{l}\text { Přítomnost/nepřítomnost webové stránky organizace v databázi } \\
\text { ENNO, RISy, př́padně ve vyhledávači Google. } \\
\text { Přístupnost webové stránky hodnocena dle intuitivnosti adresy: } \\
\text { - přímé zadání jména organizace a národní domény (.cz) - } 2 \text { body, } \\
\text { - přímé zadání jména organizace a jiné běžné domény (.org, .eu, } \\
\text {.info) - } 1 \text { bod, } \\
\text { - nutnost vyhledání přes vyhledávač - } 0 \text { bodů. } \\
\text { Aktuálnost webu hodnocena na základě nalezení bud' zjevně } \\
\text { zastaralých dat, nebo při neprovedení alespoň jedné změny v } \\
\text { uplynulém kalendářním roce } 2010 \text {. (Takto dlouhé období zvoleno } \\
\text { proto, že ne vždy lze zjistit datum poslední aktualizace.) Za aktuální } \\
\text { stránky přidělen } 1 \text { bod. }\end{array}$ \\
\hline 2: Prezentace poslání & $\begin{array}{l}\text { Použita škála 0-4 bodů. } \\
\text { - Neuvedení poslání - } 0 \text { bodů. } \\
\text { - Poslání uvedeno, ale působí zmateně nebo není vysvětleno - } 1 \text { bod. } \\
\text { - Poslání vhodně vysvětleno, ale umístěno mimo vstupní stránku - } \\
2 \text { body. } \\
\text { - Poslání vhodně vysvětleno i umístěno - } 3 \text { body. } \\
\text { - Poslání je mimo předchozího dále podpořeno dalšími nástroji (video, } \\
\text { prezentace aj.) - } 4 \text { body. }\end{array}$ \\
\hline 3: On-line dárcovství & $\begin{array}{l}\text { Použita škála 0-4 bodů. } \\
\text { - Žádná výzva k dárcovství - } 0 \text { bodů. } \\
\text { - Výzva k finančnímu dárcovství - } 1 \text { bod. } \\
\text { - Výzva k finančnímu dárcovství a zveřejnění čísla účtu - } 2 \text { body. } \\
\text { - Výzva k různým formám dárcovství a pomoci organizace - } 3 \text { body. } \\
\text { - Výzva k dárcovství, zveřejnění více možností spolupráce a usnadnění } \\
\text { a urychlení uskutečnění (DMS, PaySec a další platební nástroje) - } \\
4 \text { body. }\end{array}$ \\
\hline 4: Partnerství s veřejností & $\begin{array}{l}\text { Přitomnost výzvy k zapojení dobrovolníků, odkaz na sociální sít, nabídku } \\
\text { zasílání průběžných informací, př́padně jinou formu zviditelnění } \\
\text { nebo zprůhlednění organizace (videoreportáž, virtuální prohlídka, } \\
\text { transparentní účet). } \\
\text { Za každou jednotlivou aktivitu přidělen } 1 \text { bod, maximálně ale } 3 \text { body. }\end{array}$ \\
\hline $\begin{array}{l}\text { 5: Celková úroveň on-line } \\
\text { marketingu }\end{array}$ & $\begin{array}{l}\text { Součet získaných bodů z předchozích výzkumných otázek. Úroveň } \\
\text { byla dále zkoumána vzhledem k pưsobnosti, členství ve střešní } \\
\text { organizaci a její právní formě. }\end{array}$ \\
\hline
\end{tabular}


Pavel Bachmann: On-line marketing v neziskové organizaci: Analýza webových stránek...

\section{Charakteristika vzorku}

Vzorek zkoumaných organizací ( $\mathrm{n}=182)$ představuje přibližně $5 \%$ základního souboru, tj. všech neziskových organizací Královéhradeckého kraje. ${ }^{4} \mathrm{Z}$ hlediska právního postavení dominovala mezi subjekty začleněnými do výzkumu - podobně jako tomu je u základního souboru - právní forma občanského sdružení (148 organizací; 81,3\% ze vzorku), dále byly obsaženy církve a jejich účelová zařízení $(20 ; 11,0 \%$ ), obecně prospěšné společnosti (13; $7,1 \%)$ a jeden nadační fond $(0,5 \%)$.

Podle zaměření poslání organizace byly jednotlivé kategorie organizací ve vzorku zastoupeny poměrně rovnoměrně. Přesné složení daných organizací, včetně detailního popisu jednotlivých kategorií, obsahuje tabulka 2.

Tabulka 2: Rozdělení zkoumaných organizací dle jejich zaměření

\begin{tabular}{|c|c|c|c|}
\hline \multirow{2}{*}{$\begin{array}{l}\text { Zaměření } \\
\text { organizace }\end{array}$} & \multirow[t]{2}{*}{ Organizace, které se typicky vyskytovaly } & \multicolumn{2}{|c|}{ Počet organizací } \\
\hline & & Absolutní & $\%$ \\
\hline $\begin{array}{l}\text { Práce s dětmi a } \\
\text { mládeží }\end{array}$ & $\begin{array}{l}\text { Místní organizace Junáku - Svazu skautů a skautek ČR, } \\
\text { dětské kluby, nízkoprahová zařizení pro děti a mládež }\end{array}$ & 30 & 16,48 \\
\hline Sport & $\begin{array}{c}\text { Sportovní organizace, především tělovýchovné } \\
\text { jednoty, ale také kynologické kluby či taneční skupiny } \\
\text { a další }\end{array}$ & 27 & 14,84 \\
\hline Sociální pomoc & $\begin{array}{l}\text { Sociální poradenství, péče o seniory, azylové domy } \\
\text { (často s nepř́mou návazností na církev) }\end{array}$ & 26 & 14,29 \\
\hline $\begin{array}{l}\text { Kultura a péče o } \\
\text { památky }\end{array}$ & $\begin{array}{l}\text { Hudba a hudební festivaly, divadlo, fotografie a péče } \\
\text { o místní památky }\end{array}$ & 25 & 13,74 \\
\hline $\begin{array}{l}\text { Místní spolková } \\
\text { Činnost }\end{array}$ & $\begin{array}{c}\text { Mateřská centra, sbory dobrovolných hasičů a další } \\
\text { místní činnost }\end{array}$ & 24 & 13,19 \\
\hline Ostatní & $\begin{array}{c}\text { Vzdělávání a výzkum, ekologické, církevní a } \\
\text { humanitární organizace }\end{array}$ & 19 & 10,44 \\
\hline $\begin{array}{l}\text { Práce se } \\
\text { zdravotně } \\
\text { postiženými a } \\
\text { zdravotnictví }\end{array}$ & $\begin{array}{c}\text { Především pomoc zdravotně postiženým, naplnění } \\
\text { jejich volného času, dvě organizace zabývající se } \\
\text { prímo zdravotnictvím }\end{array}$ & 17 & 9,34 \\
\hline Regionální rozvoj & $\begin{array}{c}\text { Koordinace rozvoje území, spolupráce obcí v rámci } \\
\text { regionu }\end{array}$ & 14 & 7,69 \\
\hline Celkem & & 182 & 100 \\
\hline
\end{tabular}

4 Údaj je odhadem propočteným na základě informací poskytovaných Českým statistickým úřadem. Přesná data nejsou k dispozici. 


\section{Výsledky}

Získaná data jsou z důvodu zachování přehlednosti dále interpretována ve struktuře dř́ve vymezených výzkumných otázek.

1. Do jaké míry organizace disponují webovými stránkami? Je webová adresa intuitivní, webové stránky aktuální?

Oblast se zaměřila na zjištění pravdivosti prvních tř́ vymezených předpokladů, tj. na existenci webové stránky, snadnost přistoupení na stránku a aktuálnost informací poskytovaných webovou prezentací. Dostupná webová stránka byla k dispozici u 156 ze 182 sledovaných organizací, tj. u více než čtyř pětin $(85,7$ \%) subjektů. Podle výše zmiňovaného předpokladu dosáhl vzorek vyšší podíl organizací s webovou stránkou, než tomu bylo ve výzkumu realizovaném Rohrbacherem (2007) zaměřeném pouze na občanská sdružení.

Přímým intuitivním př́stupem $\mathrm{v}$ podobě zadání jména organizace a naší národní domény.cz by se návštěvníci dostali na internetové prezentace pouze 47 zkoumaných organizací $(30,1 \% ; n=156)$. Pokud by si hosté ve virtuálním prostoru vybavili i další obecně používané domény.org,.eu či.info, jiné obvyklé nebo snadno zapamatovatelné názvy organizace, pak by tento počet vzrostl na 80 adres $(51,3 \%$; $=156)$. Ostatní organizace, tj. téměř polovina těch, které mají webové stránky, by musely být nalezeny přes vyhledávače. Vyhledání všech organizací s dostupnou webovou stránkou pak proběhlo bez významných problémů. Neaktualizované webové stránky byly nalezeny u 14 organizací $(9,0 \%$; $=156)$. Kritérium aktuálnosti webové stránky přitom bylo určeno volně, a to tak, že v uplynulém kalendářním roce musela být na stránkách provedena alespoň jedna změna. Zjištění poslední aktualizace je totiž v některých př́ípadech obtížné, případně ho nelze vůbec určit.

\section{Jak organizace prezentuji své posláni??}

Jak již bylo zmíněno, poslání a jeho prezentace má v marketingu neziskové organizace nezastupitelný význam především $\mathrm{v}$ oblasti fundraisingu. Náš předpoklad, že na webové stránce neziskové organizace je vhodně vysvětleno její poslání, lze však potvrdit pouze u malého procenta zkoumaných organizací. Hodnocení, do kterého byly zahrnuty všechny zkoumané organizace, využívá pětibodové škály od hodnoty nula až po čtyři body. Hodnocení přitom nebralo v úvahu pouze formalizované uvedení typu „poslání naší organizace je...", nýbrž i př́ípadné zdůraznění myšlenky, kterou daná organizace hájí.

Vysvětlení účelu své činnosti bohužel neposkytuje svým klientům vysoký podíl organizací. Přestože maximální hodnocení bylo čtyřbodové, výsledná průměrná bodová hodnota byla nižší než jeden bod $(0,87 ; n=156)$. Více než polovina neziskových organizací poslání na svých webových stránkách vůbec neuvádí (87 organizací; 55,8 \%). Nejasné vysvětlení poslání, tj. př́ípady, kdy byl při hodnocení udělen jeden bod, se vyskytovalo u 13,2 \% organizací, dostačující vysvětlení, nicméně špatně umístěné, pak u 15,9\% organizací. Srozumitelné vysvětlení a vhodné umístění poslání organizace, případně podpořené dalšími nástroji, jako je prezentace nebo videoreportáž o organizaci, bylo k dispozici u méně než desetiny organizací $(8,8 \%)$.

Z hlediska působnosti organizace své poslání nejhůře prezentovaly sportovní organizace. Téměř tři čtvrtiny z nich (74,1 \%) bud' neměly webové stránky, anebo na nich neuvedly 
své poslání. Podobný podíl pak vykazovaly také organizace z oblasti „ostatní“, tj. vzdělávání a výzkum, ekologie, církevní a humanitární organizace $(73,7$ \%) a „regionální rozvoj“ (71,4 \%). Naopak lepší výsledky byly zaznamenány u organizací zabývajících se sociální pomocí, kdy alespoň částečné vysvětlení poslání poskytovalo téměř šest desetin $(57,7 \%)$ zahrnutých organizací a u organizací zaměřených na práci s dětmi a mládeží, kdy poslání měla $\mathrm{k}$ dispozici přesně polovina organizací (50\%). Nejvyšší podíl čtyřbodové kategorie, kdy je poslání jasně formulováno, dobře umístěno a podpořeno dalšími nástroji, byl zaznamenán u organizací pracujících se zdravotně postiženými a organizací z oblasti kultury a péče o památky. Detailní interpretaci rozdělení výsledků dle působnosti organizace nabízí graf 1 .

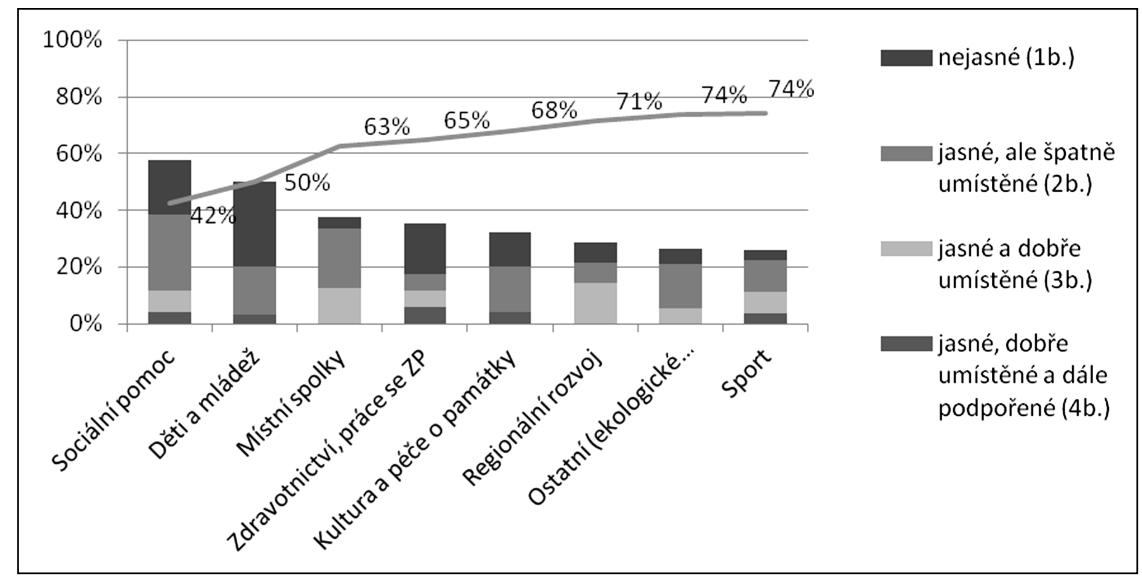

Graf 1: Úroveň prezentace poslání dle pưsobnosti organizace, včetně podílu webových stránek bez zveřejněného poslání

Výsledky tedy ukazují, že neziskové organizace nejsou připraveny na základní potřebu donátorů, tj. poznání, na jakou činnost by měli své peníze darovat. Více než šest desetin organizací poslání vůbec neuvádí na webové stránce. Je-li už uvedeno, pak je v téměř třech desetinách případů bud’ špatně vysvětleno, nebo nevhodně umístěno. V necelé desetině případů pak představení poslání odpovídá potřebám prŕípadných dárců a umožňuje realizovat např́íklad on-line dárcovství.

\section{Jaké možnosti on-line dárcovství neziskové organizace na webu nabizejí?}

Podpora virtuálního dárcovství spočívá, kromě podání jasné představy o poslání organizace, také $\mathrm{v}$ tom, že prŕípadný dárce může takovou transakci uskutečnit snadno, rychle a bezpečně (<www.darujme.cz>, 2011). V případě zajištění on-line dárcovství je třeba, aby webové stránky obsahovaly přinejmenším výzvu k poskytnutí daru, číslo bankovního účtu dané organizace, př́ípadně další apely působící na potenciálního dárce.

On-line dárcovství je mezi zkoumanými organizacemi zrejmě neznámým pojmem. Zjištěné hodnoty jsou podobné výsledkům druhé výzkumné otázky. Průměrná dosažená hodnota činila 0,82 bodu, při využití škály od 0 do 4 bodů tedy ani zde tedy nedosáhla jednoho 
bodu. Výzva k dárcovství nebyla přítomna u 91 organizací, což je více než polovina zkoumaných subjektů $(58,3 \% ; n=156)$. Pouze výzvu k dárcovství, bez uvedení čísla účtu nebo jiné formy spolupráce, uvedl malý počet organizací (5; 3,2 \%). Pochopitelně běžnější skutečností mezi studovanými subjekty bylo uvedení výzvy společně s číslem účtu (43; 27,6 \%). Malé podíly organizací se pak nacházely ve tříbodové $(10 ; 6,4 \%)$ a čtyřbodové kategorii $(7 ; 4,5$ $\%$ ), přitom právě v těchto př́padech by bylo možné hovořit o připravenosti organizací na on-line dárcovství. Ve čtvrté kategorii se nejčastěji objevovaly dárcovské sms (DMS), specifikace smluvního vztahu mezi dárcem a organizací nebo možnost uskutečnění daru přes platební nástroj PaySec.

Při rozdělení dle působnosti organizace ukazují výsledky v oblasti on-line dárcovství překvapivě odlišnou úroveň, než tomu bylo $\mathrm{v}$ předchozím případě při rozboru zveřejňovaných poslání. Nejvyšší úroveň v oblasti on-line dárcovství vykazují organizace z oblasti práce se zdravotně postiženými a zdravotnictví. Přesně tři čtvrtiny z nich $(12 ; 75,0 \%$; $=16)$ poskytují přinejmenším výzvu $\mathrm{k}$ dárcovství. Naopak nejhorší výsledky byly opětovně zjištěny u sportovně orientovaných organizací $(17,4 \% ; n=23)$.

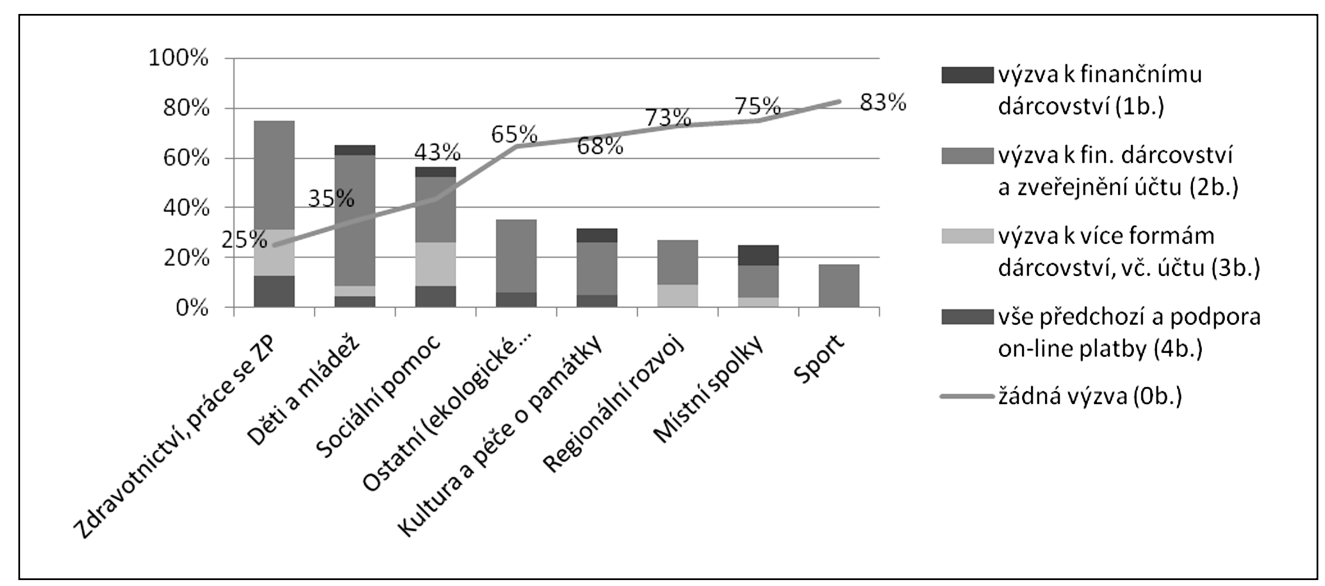

Graf 2: Úroveň on-line dárcovství dle pưsobnosti organizace, včetně podílu stránek bez výzvy k dárcovství

Dárce zpravidla za svi̊j př́íspěvek nic neočekává, nicméně poděkování ve formě zveřjnění dárce např́klad na webových stránkách by ze strany neziskové organizace měla být nejen slušností, ale i samozřejmostí. Prezentace dárce organizace je proto dalším předpokladem, který byl ověřován. U zkoumaných organizací byl zjištěn mírně vyšší podíl těch, kteří dárce určitým způsobem prezentují $(51,9 \%$; $=156)$, naopak zbylé organizace $(48,1 \%$; $\mathrm{n}=156$ ) dárce na stránkách neuvádějí. 
4. Umožňuji webové stránky navázáni partnerství s veřejností (udržení vztahu, materiální pomoc, konzultace, dobrovolnictví aj.)?

Pro zajištění pravidelného kontaktu s organizací je však v současné době nutné použít i fenoménu sociálních sítí, jako jsou Facebook, Twitter a další. Ukazuje se totiž, že zejména u mladší generace tyto technologie zaujímají stále větší prostor (Veselá a Šmahel 2009). $\mathrm{Z}$ toho důvodu byla sledována také účast neziskových organizací v sociálních sítích.

Navázání vztahu s veřejností kromě samotných webových stránek využila méně než třetina organizací zahrnutých ve studii (44 organizací; 28,2\%;n=156). Některé organizace pak využívaly více způsobů komunikace než jeden. Nejvíce organizací $(21 ; 13,5 \%)$ mělo k dispozici audio nebo video nahrávku přibližující činnost organizace nebo vybízející k zapojení. Necelá desetina organizací (14; 9 \%) pak měla k dispozici RSS (Really Simple Syndication) umožňující automatické zasílání obsahu webové stránky. Otázkou však zůstává, zda prrítomnost RSS neodráží jen jednu z mnoha funkcionalit nových redakčních systémů pro správu webových stránek nebo je-li skutečně záměrem organizace a obsah webu je z toho důvodu pravidelně aktualizován. Odkaz na prezentaci organizace v sociální síti uveřejněný na webové stránce mělo 11 organizací $(7,1 \%)$. Nejčastěji se vyskytoval Facebook, pouze $\mathrm{v}$ jednom prŕípadě pak sociální sít' Myspace. Překvapivě malé procento organizací využívá také výzvu k dobrovolnictví $(10 ; 6,4$ \%) a transparentní účet $(2 ; 1,3 \%)$. Komplexní informace o využívaných komunikačních nástrojích poskytuje tabulka 3.

Tabulka 3: Nástroje využívané pro kontakt s veřejností (kromě samotných webových stránek)

\begin{tabular}{|l|c|c|}
\hline Nástroj využitý pro kontakt s veřejností & Počet organizací & \% podíl při n=156 \\
\hline TV kanál, videospot, web kamera, e-learning & 21 & 13,5 \\
\hline RSS - automatické zasílání obsahu webu & 14 & 9,0 \\
\hline Sociální síf (facebook, my space) & 11 & 7,1 \\
\hline Výzva k dobrovolnictví & 10 & 6,4 \\
\hline Zasílání zpráv na e-mail, účast v klubu & 6 & 3,8 \\
\hline Transparentní účet & 2 & 1,3 \\
\hline
\end{tabular}

5. Jaká je celková úroveň poskytovaného on-line marketingu? Rozdělení dle působnosti, začleněni do střě̌ní organizace a právní formy.

Míra úrovně byla zjišt'ována z kvality marketingových činností dostupných na webových stránkách posuzovaných organizací, odpovídá tedy pouze on-line činnostem realizovaným organizacemi na jejich webových stránkách. Skóre je součtem výsledků hodnocení za skóre dosažené v rámci dř́ve hodnocených oblastí. Maximální skóre mohlo činit 14 bodů. Organizace zařazené do výzkumu dosáhly průměrného skóre 4,00 body, tj. 28,6 \% maximálního hodnocení. Při pohledu na dosažené souhrnné skóre jednotlivých organizací je zajímavé, že se na předních místech umístily především organizace církevní nebo církví podporované. Jedná se například o Sdružení Neratov ( $<$ www.neratov.cz $>)$, A. Rocha - křest'ané chrání př́rodu ( $<$ www.arocha. org/cz-cs>) či Diakonie ČCE - středisko Milíčův dům (<www.milicak.cz>).

Rozdíly mezi jednotlivými kategoriemi z hlediska působnosti organizace odpovídaly již dříve zjištěným údajům. Nejvyšší průměrné skóre dosáhly organizace z oblasti práce se 
zdravotně postiženými a zdravotnictví ( 5,41 bodů) a sociální pomoci (4,73 bodů). Hodnot mezi třemi a čtyřmi body dosáhly organizace ze čtyř oblastí: organizace zaměřené na práci s dětmi a mládeží (3,90 bodů), kulturní organizace a organizace pečující o památky $(3,76$ bodů), místní (zpravidla venkovské) spolky (3,75 bodů) a ostatní organizace, které nebylo možné zařadit do žádné z kategorií (3,53 bodů). Nejnižší skóre pak bylo nalezeno u sportovně orientovaných organizací $(2,78$ bodů) a organizací zaměřených na regionální rozvoj (2,71 bodi̊).

Předmětem dalšího zkoumání byly rozdíly v poskytované kvalitě podle toho, zda organizace byla či nebyla začleněna $\mathrm{v}$ zastřššjící organizaci (církevní organizace nebyly $\mathrm{v}$ tomto případě začleněny ani do jedné z kategorií). Průměrné hodnoty byly vyšší u organizací, které dle informací na webových stránkách nejsou členy žádné zastř̌ešující organizace (4,68 bodů), než u těch, které o členství na webové prezentaci informují ( 4,18 bodů).

Závěrečnou oblastí ověření byl vliv právní formy. Zpracování výsledků se omezilo pouze na organizace s právní formou občanského sdružení, obecně prospěšné společnosti a církve. Ve vzorku se totiž vyskytovala pouze jedna organizace s právní formou nadačního fondu, respektive zájmového sdružení. Nejvyšší průměrné hodnoty reflektující úroveň on-line marketingu realizovaného na webových stránkách byly dosaženy u neziskových organizací s církevní právní formou ( 4,55 bodů), následovaly obecně prospěšné společnosti ( 4,01 bodů) a občanská sdružení ( 3,69 bodů).

\section{Diskuse a závěr}

Nezbytnost výzkumu v oblasti umocňuje nejen rychlý rozvoj internetu a přesun marketingových aktivit z off-line na on-line formu (Hart a kol. 2010), ale také vysoký potenciál využití sítě sítí neziskovými organizacemi (Hart 2006). Předložená studie jako jedna z prvních na našem území mapuje on-line marketing realizovaný neziskovými organizacemi na webových stránkách. Poskytuje tak základ pro detailnější zkoumání problematiky. Pro další bádání lze jednoznačně doporučit hlubší konkretizaci řešeného problému se zaměřením na některou v článku řešených výzkumných otázek.

Při interpretaci výsledků je třeba vzít v úvahu, že na webové stránce neziskové organizace nemusí být obsaženy všechny danou organizací používané nástroje on-line marketingové komunikace. Zároveň je důležité zohlednit fakt, že byly hodnoceny neziskové organizace již př́itomné v databázích. Tedy takové, které informace o sobě bud' do databáze samy vložily (databáze ENNO), nebo jejichž data tam byla vložena na základě předchozí spolupráce se státní správou (databáze RIS). Přes tuto skutečnost ukazují následující výsledky na to, že organizace začleněné do výzkumu mají v oblasti on-line marketingu velké rezervy:

- Webovou stránku mají k dispozici více než čtyři pětiny zkoumaných organizací, přibližně polovina z nich disponuje intuitivní webovou adresou. Všechny organizace s webovou stránkou je možné na internetu snadno nalézt prostřednictvím vyhledávačů.

- Srozumitelným a na stránkách vhodně umístěným posláním disponuje necelá desetina $\mathrm{z}$ analyzovaných subjektů. Naopak více než polovina organizací zařazených do výzkumu své poslání na webové síti vůbec neuvádí.

- Výzvu k dárcovství uvádějí na svých webových stránkách pouze dvě pětiny organizací. 
Pavel Bachmann: On-line marketing v neziskové organizaci: Analýza webových stránek...

Dobře komunikovat svá přání vzhledem k dárcům a poskytnout jim rychlé a spolehlivé platební nástroje umí přibližně desetina organizací.

- O navázání dlouhodobého vztahu s veřejností (kluby přátel, výzvy ke spolupráci či dobrovolnictví a další formy) se prostřednictvím webové sítě snaží méně než třetina organizací. Méně než desetina ze zkoumaných organizací na svých webových stránkách uvádí odkaz na sociální sítě.

- Nejvyšší úroveň on-line marketingu dosahují organizace zaměřené na pomoc zdravotně postiženým, na zdravotnictví a sociální pomoc. Na opačném konci se s nejnižší úrovní internetového marketingu nacházejí organizace orientované na sportovní činnosti. Z hlediska právních forem pak nejvyšší úroveň on-line marketingu vykazují církevní organizace, následované obecně prospěšnými společnostmi. Zřetelně nižší úroveň byla pak zaznamenána u organizací s právní formou občanského sdružení.

\section{Literatura}

BACHMANN, Pavel. Disparity obcí v oblasti poskytování informací. E+M Ekonomie a Management, 2010, roč. 11, č. 3, s. 116-126. ISSN 1212-3609.

BACHMANN, Pavel. Transparentnost neziskového sektoru: vybrané výsledky primárního výzkumu. Sbornik př́spěvků z mezinárodní konference Hradecké ekonomické dny 2011. Univerzita Hradec Králové, 2011, s. 12-19. ISBN: 978-80-7435-100-6.

BENÁČEK, Vladimír; FRIČ, Pavol; POTU゚ČEK, Martin. Trh, stát a občanský sektor ve vzájemných vztazích. In: Strategické volby pro českou společnost: teoretická východiska. Praha: Nakladatelství SLON, 2008, s. 151-171. ISBN: 978-80-7419-001-8.

BENSON, Shapiro, P. Marketing in Nonprofit Organizations. Nonprofit and Voluntary Sector. 1974, s. 1-16. ISSN: 1479-103X.

BROWN, Howard, H.; RUHL, Donald, L.: Breakthrough Management for Not-for-Profit Organizations: Beyond Survival in the 21st Century. Westport: Praeger, 2003. 255 s. ISBN: 1-56720-639-5.

BLAŽKOVÁ, Martina. Jak využít internet v marketingu. Praha: Grada Publishing, 2005. 156 s. ISBN: 80247-1095-1.

Darujme.cz - Bezpečná cesta pro Vaše dary. [on-line]. Darujme.cz, Sdružení VIA, 2011 [cit. 2011-05-03]. Dostupné na $<$ www.darujme.cz $>$

DRUCKER, Phillip, F. Řizení neziskové organizace: praxe a principy. Praha: Management Press, 1994. 184 s. ISBN 80-85603-38-1.

GANDIA, Juan, L.; ARCHIDONA, Maria, C. Determinants of Website Information by Spanish City Councils. Online Information Review, 2008, roč. 32, č. 1, s. 35-57. ISSN: 1468-4527.

HART, Ted; MACLAUGHLIN, Steve; GREENFIELD, James, M.; GEIER, Phillip, H.. Internet for Nonprofits Management: Strategies, Tools \& Trade Secrets. Hoboken, New Jersey: John Willey and Sons, 2010. 414 s. ISBN: 978-0-470-53956-9

HART, Theodore R. ePhilanthropy: Using the Internet to Build Support. International Journal of Nonprofit and Voluntary Sector Marketing, 2006, roč. 7, č. 4, s. 353-360. ISSN: 1479-103X.

HEWSON, Claire. Gathering Data on the Internet. Qualitative Approaches and Possibilities for Mixed Methods Research. The Oxford Handbook of Internet Psychology. New York: Oxford University Press, 2007, s. 405-428. ISBN: 978-0-19-856800-1.

INGEHOFF, Diana; KOELling, Martina A. The Potential of Web Sites as a Relationship Building Tool for Charitable Fundraising NPOs. Public Relations Review, 2009, roč. 35, č. 1, s. 66-73. ISSN: 0363-8111. 
JAE Wook Kim; JIHO Choi; QUALLS, William; KYESOOK, Han. It Takes a Marketplace Community to Raise Brand Commitment: The Role of Online Communities. Journal of Marketing Management, 2008, roč. 24, č. 3/4, s. 409-431. ISSN: 0267-257X.

JANOUCH, Viktor. Internetový marketing. Prosad'te se na webu a sociálních sitich. Praha: Computer Press, 2010. 304 s. ISBN: 80-247-0016-6.

KOHLI, Ajay, K.; JAWORSKI, Bernard, J. Market Orientation: The Construct, Research Propositions, and Managerial Implications. Journal of Marketing, 1990, roč. 54, s. 1-18. ISSN: 0022-2429.

KOMÁRKOVÁ, Jitka; MÁCHOVÁ, Renáta; BEDNARČÍKOVÁ, Ilona. Požadavky uživatelů na kvalitu webových stránek městského úřadu. E+M Ekonomie a Management, 2008, roč. 11, č. 3, s. 116-126. ISSN 1212-3609.

KOTLER, Philip. Marketing management. Praha: Grada Publishing, 2001. 720 s. ISBN: 80-247-0016-6.

KOTLER, Philip. Reconceptualizing Marketing: An Interview with Philip Kotler. European Management Journal, 1994, roč. 12, č. 4, s. 353-361. ISSN: 0263-2373.

KOTLER, Philip; KELLER, Kevin L. Marketing Management. Praha: Grada Publishing, 2007. 788 s. ISBN: 978-80-247-1359-5.

LEDVINOVÁ, Jana. Základy fundraisingu [on-line]. České centrum fundraisingu, 1996 [cit. 2011-0503]. Dostupné na < www.fundraising.cz/knihy-v-elektronicke-podobe $>$

Nadace Via a Nadace Vodafone přispějí v roce 2010 k rozvoji individuálního dárcovství v Čechách [on-line, tisková zpráva ze dne 14. 1. 2010]. [Cit. 2011-05-14.] Nadace Via. Dostupné na <www. nadacevia.cz/cz/pro-media/tiskove-zpravy/nadace-via-a-nadace-vodafone-prispeji-v-roce-2010-k-rozvoji-individualniho-darcovstvi-v-cechach>

ROHRBACHER, Tomáš. Rozbor webových stránek občanských sdružení; analýza problémů transparentnosti a návrh na její zlepšení [on-line]. [Cit. 2011-05-03.] Dostupné na <www.mvcr.cz/ soubor/ studie-rohrbacher-pdf.aspx>

SARGEANT, Adrian. Marketing Management for Nonprofit Organizations. Oxford: Oxford University Press, 2005. 408 s. ISBN: 0-19-927182-8.

SMITH, BUCKLIN \& Associates. The Complete Guide to Nonprofit Management. New York: John Willey and Sons, 2000. 374 s. ISBN: 0-471-38062-8.

ŠEDIVÝ, Marek; MEDLÍKOVÁ, Olga. Úspěšná nezisková organizace. Praha: Grada Publishing, 2009, 160 s. ISBN: 978-80-247-2707-3.

VAŠTÍKOVÁ, Miroslava. Marketing služeb efektivně a moderně. Praha: Grada Publishing, 2008. $232 \mathrm{~s}$. ISBN: 978-80-247-2721-9.

VESELÁ, Martina; ŠMAHEL, David: Online komunity v České republice: Analýza členů a jejich sociálního kontextu. Sociální studia, 2009, č. 2, s. 55-72. ISSN 1214-813X.

Zpráva o stavu neziskového sektoru v České republice za rok 2008 [on-line]. 2009. Neziskovky.cz. [Cit. 2011-05-03.] Dostupné na: <www.neziskovky.cz/cz/fakta/ zpravodajstvi /svet/4112.html>

\section{Autor}

Pavel Bachmann je odborným asistentem katedry managementu Univerzity Hradec Králové. Dlouhodobě se věnuje managementu neziskových organizací a ve svých publikacích se zaměřuje především na oblasti strategického řízení a transparentnosti. V současnosti je odborným garantem dvousemestrálního vzdělávacího kurzu pro manažery neziskových organizací pořádaného Nadací rozvoje občanské společnosti ve spolupráci s Univerzitou Hradec Králové. Kontakt: pavel.bachmann@uhk.cz 